\title{
Mandibula-rezekált páciens protetikai ellátása implantációs fogpótlással
}

\author{
Esetismertetés
}

\author{
DR. DÉRI TAMÁS, DR. KÁDÁR LÁSZLÓ
}

\begin{abstract}
A maxillofaciális régióban a különböző daganatos kórképek gyógyítása során végzett radikális, csonkoló mútétek; balesetek, roncsolásos sérülések helyreállítása komplikált rehabilitációs technikákat igényel. Az alsó állcsont és az annak régiójába tartozó lágyrész-képletek esetében a defektusok megszüntetése igen nehéz feladat. Amennyiben a mandibula folytonossága sebészi módszerekkel nem biztosítható, a protetikai ellátás során további akadályokkal szembesülünk. Ha a rágószerv-rendszer integritása, funkcionális egysége megbomlik, nemcsak a kedvezőtlen klinikai anatómiai viszonyok (beszúkült, esetleg részlegesen megszúnt vestibularis áthajlás, heges bucca stb.) jelentenek kihívást, hanem az állkapocs patológiás mozgása is kialakul, a temporomandibuláris ízület múködése az érintett oldalon gyakorlatilag megszúnik, az ellenoldalon viszont túlterheltté válik. Ilyen esetekben komoly kihívás egy múködőképes fogmű kivitelezése, ebben nagy segítséget nyújt az implantációs protetika, amelynek tárháza nélkül szinte lehetetlen feladat a korrekt ellátás.
\end{abstract}

Kulcsszavak: mandibula-rezekció, implantátum, overdenture, rehabilitáció

\section{Bevezetés}

A szájüregi daganatok közül a nyelvrák mintegy 3040\%-ot tesz ki. A páciensek zöme férfi, igen jelentős az alkohol és a dohányzás hatása mint súlyosbító, hajlamosító tényező, csakúgy, mint az egyéb intraoralis daganatok esetében. Leggyakrabban a nyelvszél középső harmadában fordul elő, a nyelvháton igen ritka, és itt is csak a nyelvgyökön jelentkezik. Klinikailag két formája ismert: az infiltráló és az exophyt típus. Szövettani szempontból a kevésbé differenciált forma fordul elő többször. Korán és gyakran képez áttétet. Prognózisa rossz, ezért terápiájában a komplex kezelés javasolt. A sebészi fázis során, amennyiben az alsó állcsont egy része is eltávolításra kerül, nagyon fontos az állkapocs folytonosságának biztosítása. Ennek óriási irodalma van, de a jól bevált technikák ellenére sem oldható meg mindig a csontos képletek újraegyesítése. Ilyen esetekben a protézis készítésének lehetőségei igencsak korlátozottak, mivel az alátámasztatlan lágyrészgraftok teherviselésre alkalmatlanok, rájuk az alaplemezt nem lehet kiterjeszteni. A fogatlan alsó állcsontra funkcióképes teljes lemezes fogpótlást készíteni még ép anatómiai viszonyok mellett is az egyik legnehezebb protetikai feladat, rezekált mandibula esetén a nehezítő körülmények (hegek, állkapocs-ízületi rendellenességek, elégtelen elhorgonyzási lehetőségek stb.) tovább rontják a helyzetet. Sokszor csak implantációs fogmü készítése adhat kielégítő eredményt [5].
A következőkben egy nyelvgyöki rosszindulatú daganat miatt operált, féloldali mandibula-defektussal érkezett páciens számára készült fogpótlás klinikai munkafázisait mutatjuk be.

\section{Esetismertetés}

Páciensünk 51 éves férfi, foglalkozása irodai alkalmazott. Klinikánkon 2010-ben jelentkezett fogpótlás készítése céljából. Korábban készült részleges lemezes fogpótlásait részben a fogak elvesztése, részben a megváltozott, speciális anatómiai viszonyok miatt már nem tudta viselni. A pácienst 2008-ban fej-nyak régióban elhelyezkedő tumor miatt operálták, más kezelést befolyásoló betegsége nincs.

A betegnél 2007-ben jobb oldali nyelvgyöktumort diagnosztizáltak, ennek kezelése során chemo-radioterápiában részesült, az elváltozás teljes regressziót mutatott, de kezelés közben a primer tumorból észlelt erős vérzés miatt jobb oldali arteria lingualis ligaturát végeztek. A rendszeres kontroll-vizsgálatok egyikén 2008-ban recidivát észleltek a nyelvgyök és nyelvtest jobb oldalán. A kórszövettani vizsgálat malignitást mutatott: carcinoma planocellulare keratoides recidivans. Mútéti megoldásra került sor: jobb oldali radicalis nyaki blockdissectio és a tumor resectiója (nyelvtest, nyelvgyök, mandibula bázisa és teste); a kialakult defektus pótlása musculus pectoralis major myocutan lebennyel. Postoperatív táplálás 
biztosítására tápláló gyomorsipolyt alakítottak ki. 20 nap után kielégítő nyelési funkció mellett a beteget dekanülálták.

Jelentkezésekor a stomato-onkológiai vizsgálat negatív postoperatív képet mutatott. A harapási forma a korábbi fogpótlások alapján megítélve eugnath volt. Ízületvizsgálat: a jobb oldali ramus mandibulae és a corpus mandibulae egy része hiányzik, ezért a mandibula jobbra deviál szájnyitáskor. Felső állcsont: teljesen fogatlan felső állcsont, megtartott U-alakú állcsontgerinc, kevéssé kifejezett tuberek. Alsó állcsont: teljesen fogatlan alsó állcsont, a nem resecált területen megtartott fogatlan állcsontgerinc.

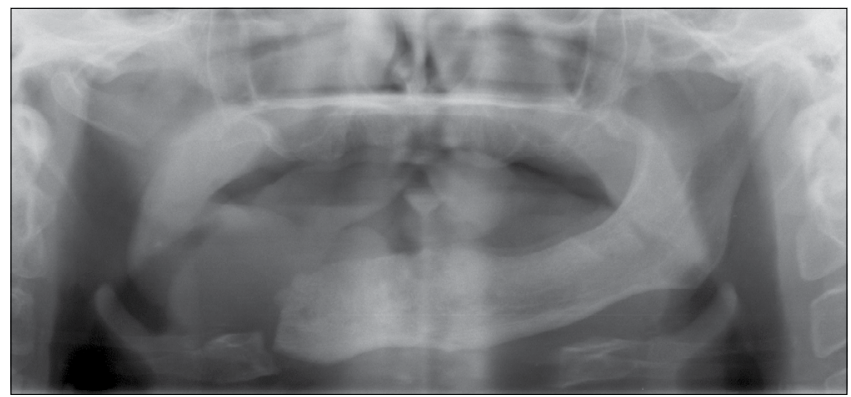

1. kép: Kiindulási OP-felvétel, még az implantációt megelőzően
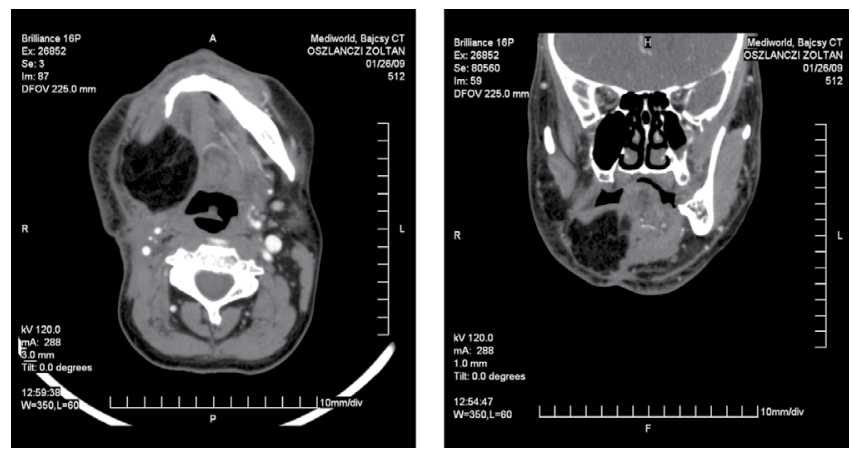

2. kép: Kiindulási CT-felvételek, még az implantációt megelőzően

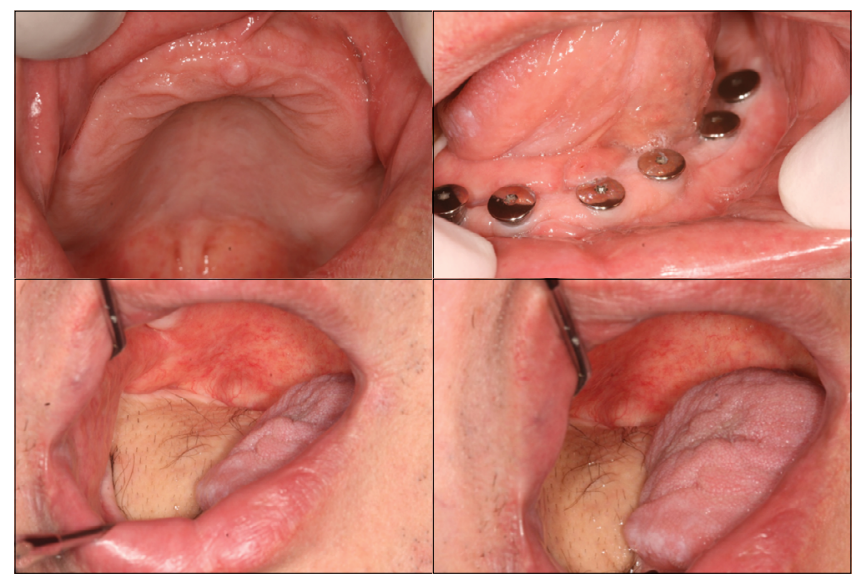

3. kép: A páciens státusza a protetikai rehabilitáció kezdetekor

\section{Előkészítő múveletek}

Szájsebészeti - protetikai: az implantológiai konzultáció a mandibula frontalis és bal oldali régiójában implantátumok behelyezését lehetségesnek ítélte. 2010-ben $6 \mathrm{db}, 10 \mathrm{~mm}-\mathrm{es}$, Straumann Tissue Level $\varnothing 4,1 \mathrm{~mm}$ RN, SLActive implantátum (International Headquarters Institut Straumann AGPeter Merian-Weg 12 CH-4002 Basel, Switzerland) került beültetésre. Klinikánkon a gyógyulási csavarokkal lezárt, megfelelően osseointegrálódott implantátumokkal jelentkezett.

\section{Kezelési terv}

- Felső állcsont: 12 fogat pótló teljes lemezes fogpótlás akrilát alaplemezzel

- Alsó állcsont: 11 fogat pótló, mintára öntött technológiával készült, implanto-mucosalis megtámasztású, implantátumokon rögzülő Dolder rendszerű stéges mezostruktúrán lovasokkal elhorgonyzott részleges lemezes fogpótlás, a rezekált területre a csontalapzat hiánya miatt nem terjeszthető ki a fogpótlás Müízület kialakítása nem volt indokolt, mert a páciens az alsó állcsontot szájzárás során kielégítő pontossággal megfelelő helyzetbe pozicionálta [1, 2].

\section{Kezelés folyamata}

A fogpótlás elkészítésének első lépéseként felső anatómiai és alsó szituációs lenyomatot vettünk (Tropicalgin, Zhermack), a megfelelő minták a fogtechnikai laboratóriumban készültek el. A felső állcsontra hagyományos akrilát egyéni kanalat, az alsó állcsontra nyitott akrilát egyéni kanalat kértünk az implantátumok lenyomatozásához.

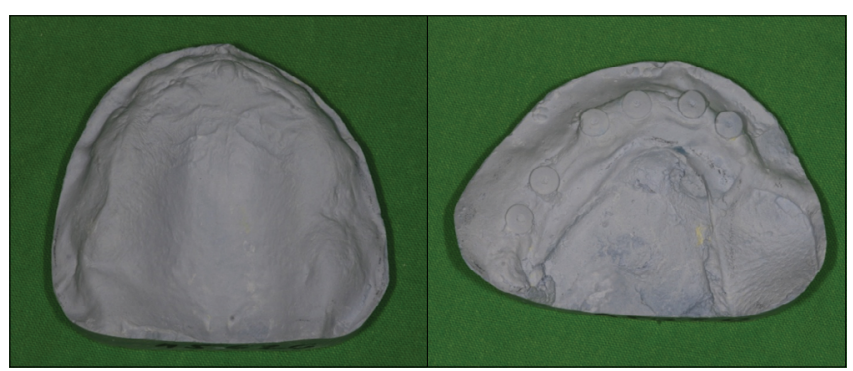

4. kép: Felső anatómiai- és alsó szituációs minta

A felső egyéni kanalat befunkcionáltuk, majd funkciós lenyomatot vettünk cink-oxid-eugenol paszta lenyomatanyaggal (Impression Paste, SS White). Az alsó állcsontról nyitott kanalas technikával implantátum-szintű lenyomatot vettünk poliéter lenyomatanyaggal (Impregum Penta Soft - 3M ESPE), majd még a rendelőben csatlakoztattuk a technikai analógokat [4]. 


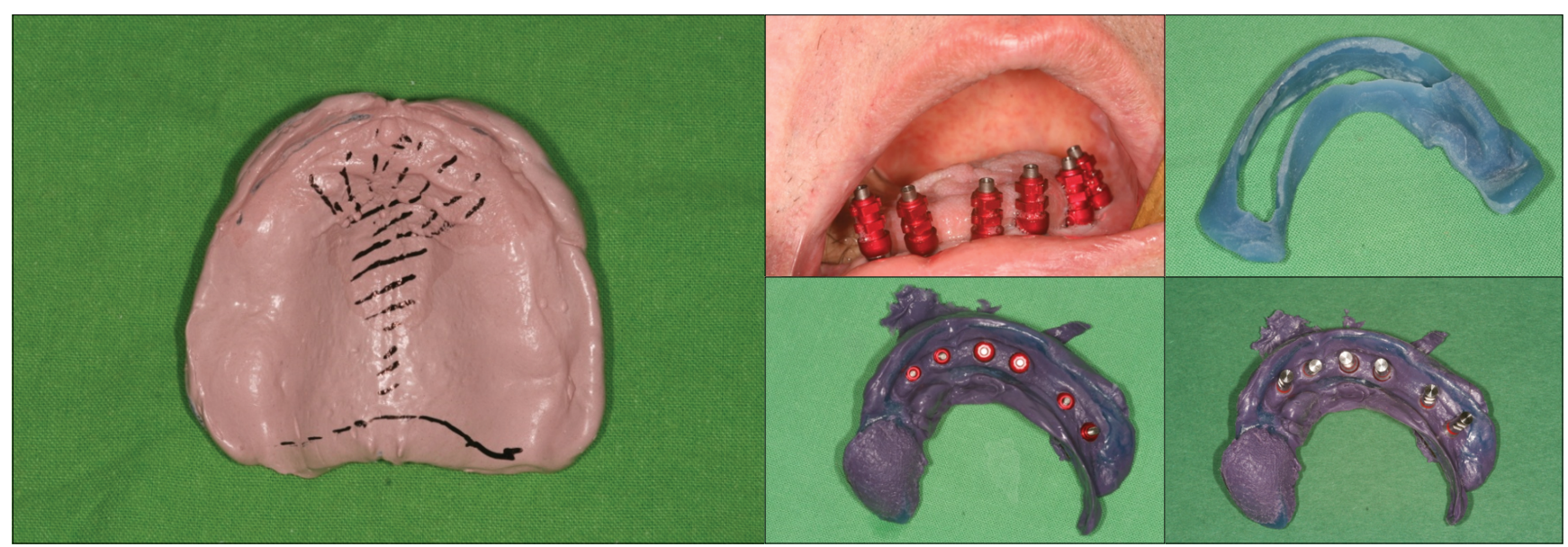

5. kép: Felső funkciós- és alsó szituációs lenyomat

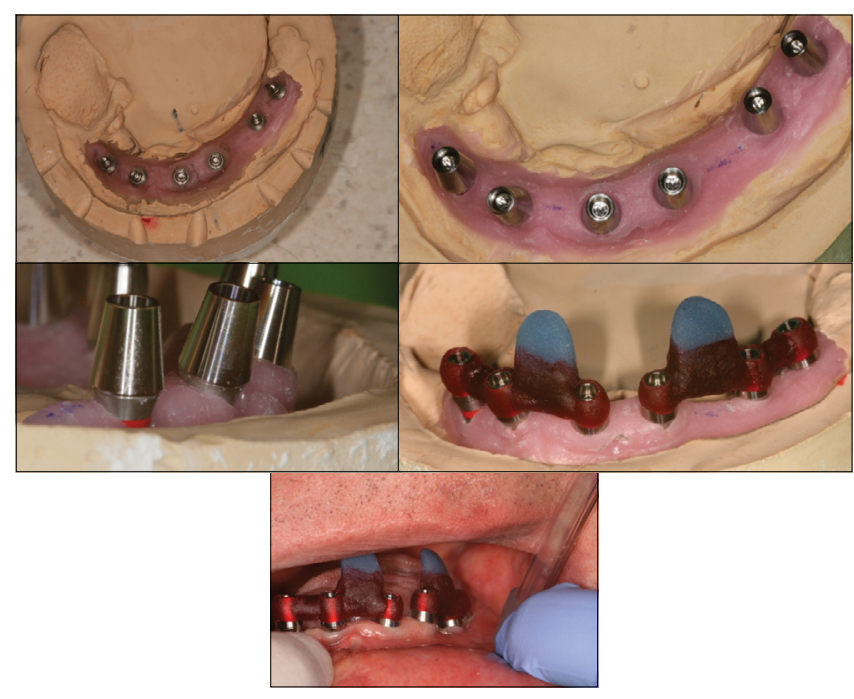

6. kép: Validáló, átvivő kulcsok alkalmazása
Nagy kiterjedésű implantációs fogpótlásoknál, különösen csavarozott rögzítés esetén követelmény az abszolút feszülésmentes illeszkedés az implantátumokon. Ezért a lenyomat alapján öntött mintát validálni kell. Esetünkben a mintára helyezett implantátumfejekre a mezostruktúra későbbi, még nem frézelt titán „sapkáit" csavarral rögzítették, ezeket önkötő mintázó-múanyaggal (Pattern Resin - GC) összekötve egy átvivő, ellenőrző kulcs jött létre, melyet Sheffield-tesztnek alávetve meggyőződhettünk lenyomatunk és a minta pontosságáról $[3,6]$. (6. kép)

Mezostruktúrával elhorgonyzott fogpótlások esetén nagyon fontos szempont, hogy a rögzítő merevítőrúd-rendszer és a lovasok elférnek-e a leendő fogmú alatt, nehogy túldimenzionált, kedvezőtlen esztétikájú és funkciójú protézis készüljön. Ezért a korrektnek ítélt alsó és felső mintára harapási sablonok készültek, melyekkel meghatároztuk a centrális okklúziós helyzetet, és

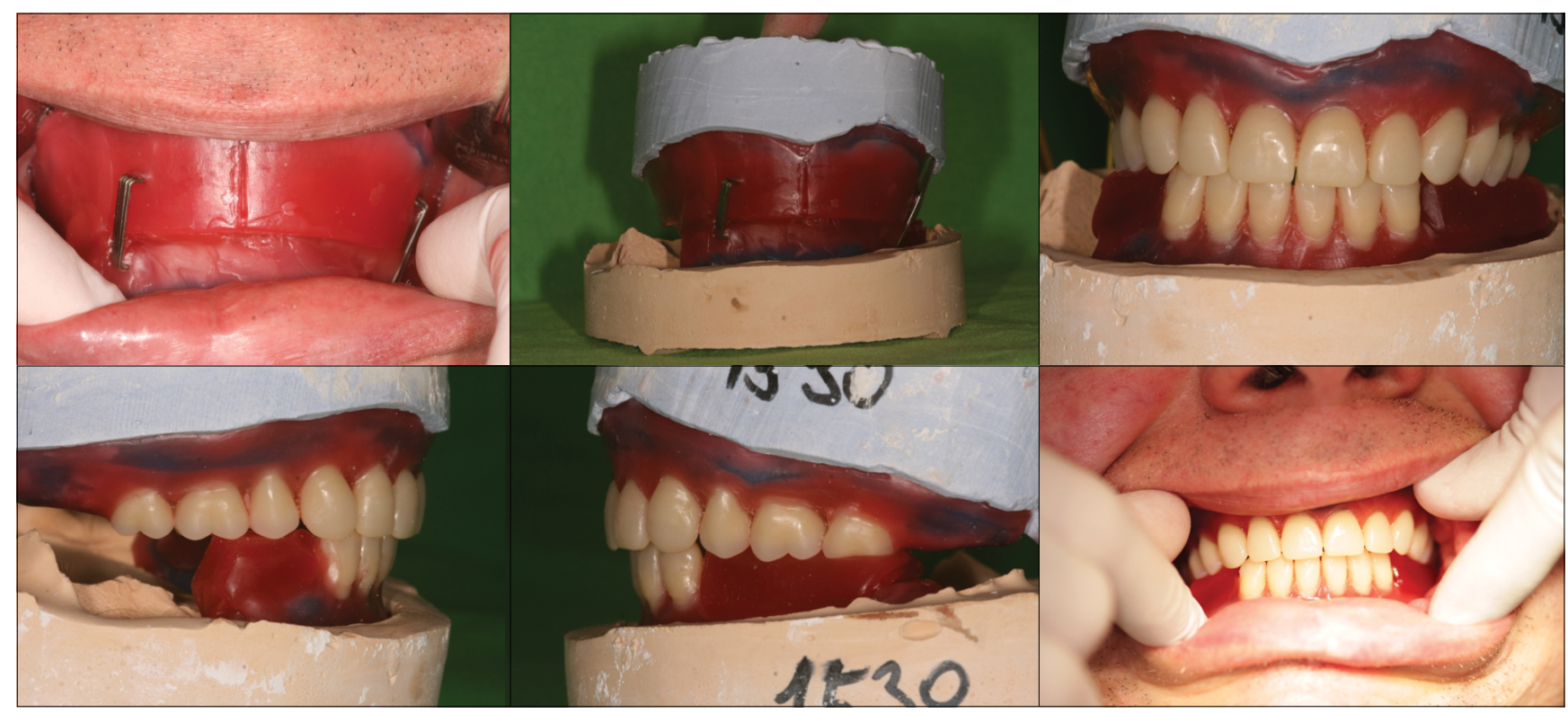

7. kép: Centrális okklúzió meghatározása és diagnosztikus próbafogsor az artikulátorban és a szájban 
fogszínválasztást követően diagnosztikus fogfelállítást és próbafogsorokat kértünk. Ezek segítségével a páciens számára megfelelő, általa elfogadott próbafogsorhoz jutunk, mely leblokkolásával és a szilikonblokkmintára visszahelyezésével mind a fogtechnikus, mind a fogorvos meggyőződhet arról, hogy vertikális és horizontális dimenzióban is megfelelő helykínálat áll rendelkezésre a leendő fogpótlás „alatt” a rögzítő rendszer számára. Miután ezt kielégítőnek találtuk, kértük a mezostruktúra elkészítését. A laboratórium ezt elöre gyártott, titánelemek felhasználásával, lézerhegesztési eljárás segítségével végezte el. (7. kép)

A stégekkel vázpróbát végeztünk, itt is figyelve természetesen a Sheffield-teszt követelményeire. (8. kép) A jól illeszkedő merevítőrudakra a laboratórium mintára öntött fémlemezt készített, melyet szintén lepróbáltunk. (9. kép)

Mivel az artikulátorban végig a korábbi próbafogsor „alá” dolgoztunk, nem volt szükség újabb harapásvételre. Ezért most már a véglegesnek szánt próbafogsorokat kaptuk a fogtechnikától. Ezek próbájuk során megfelelőnek bizonyultak, tehát kérhettük készre készítésüket. (10. kép)

A kész fogmúveket a páciensnek a szükséges instrukciók kíséretében átadtuk. (11.,12. kép)

\section{Megbeszélés}

A páciens a rövid és hosszú távú kontrollvizsgálatokon megjelent, fogpótlásait panaszmentesen viseli, az egyedi anatómiai variációk miatt volt szükség eleinte gyakrabban korrekciók elvégzésére. Az okklúziós és artikulációs viszonyok utólagos beállítására is ekkor került sor. A megrövidült fogív és a kezdeti megszokási nehézségek ellenére elmondható, hogy az implantációs protetika segítségével sikerült a lehetőségekhez képest

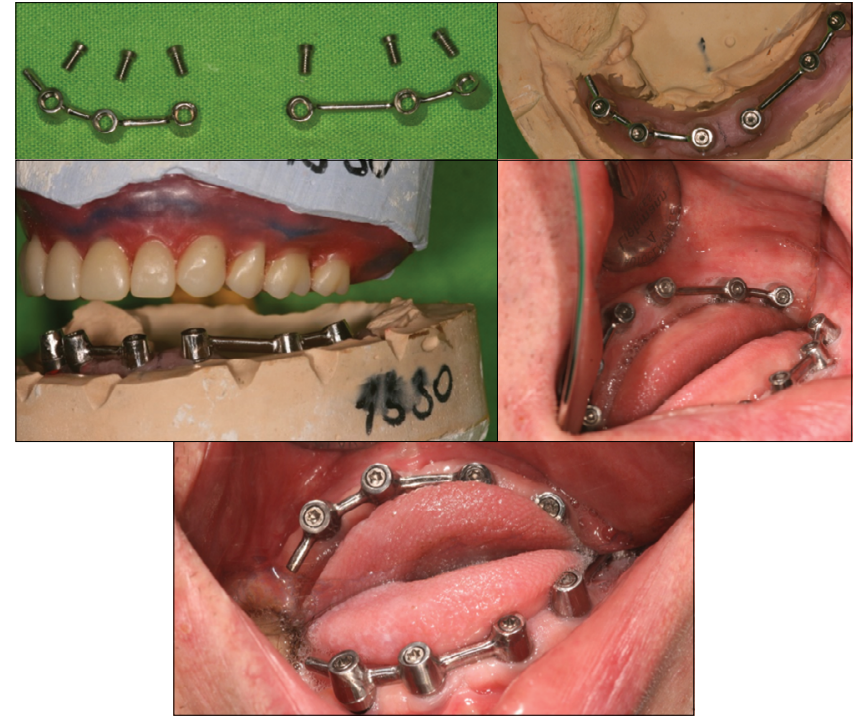

8. kép: Vázpróba

kielégítő rágófunkciót biztosítani a páciens számára. Minél korábban tudjuk a végleges fogpótlást elkészíteni, annál jobb eredményt érhetünk el a rehabilitáció során, kevésbé alakulnak ki olyan parafunkciók, melyek kiiktatása igen nehéz feladat.

\section{Irodalom}

1. Beumer J, Marunick MT, Esposito SJ: Maxillofacial Rehabilitation: Prosthodontic and Surgical Management of Cancer-related, Acquired, and Congenital Defects of the Head and Neck III. Quintessence Pub. 2011; 0867154985, 9780867154986

2. Cantor R, Curtis TA.: Prosthetic management of edentulous mandibulectomy patients: part II, Clinical procedures. J Prosthet Dent. 1971; 25: 546-555. https://doi.org/10.1016/0022-3913(71)90213-7 3. De La Cruz Je, Funkenbusch PD, Ercoli C, Moss ME, Graser GN,

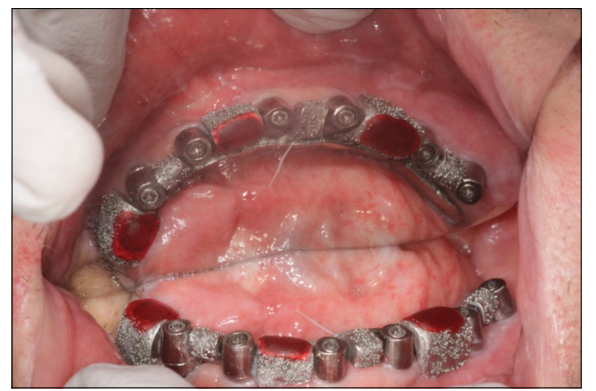

9. kép: Fémlemez próbája
10. kép: Végleges próbafogsorok az artikulátorban és a szájban

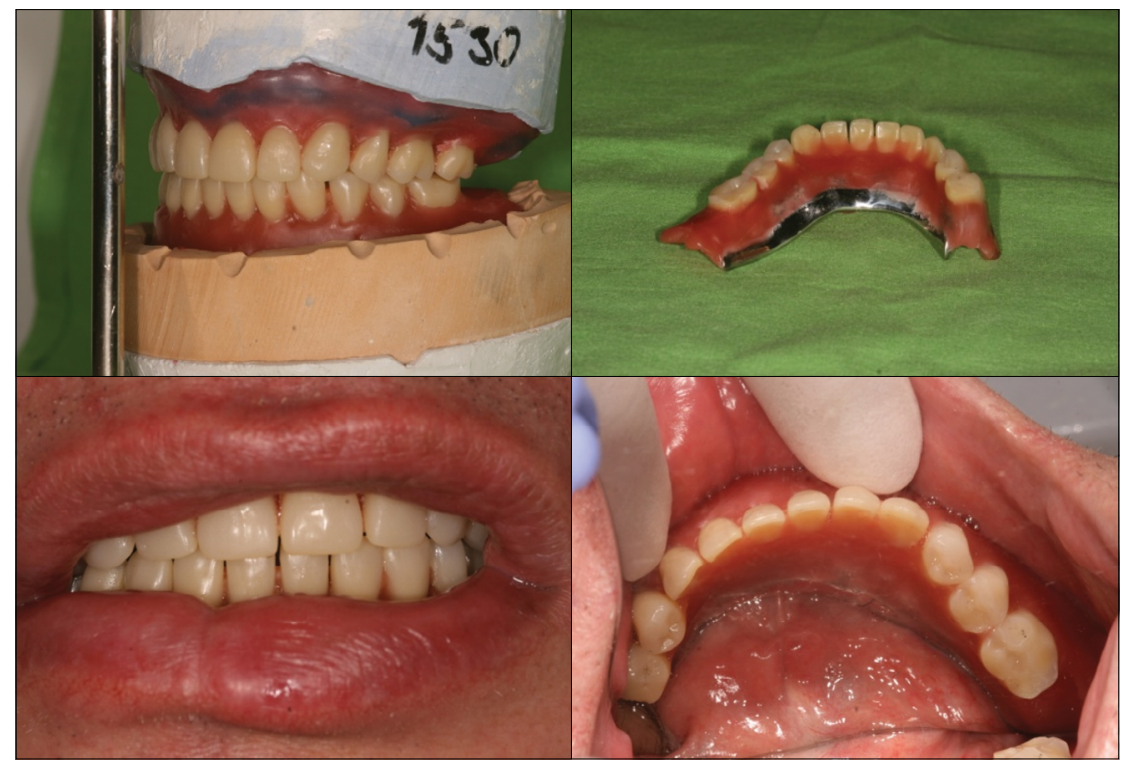



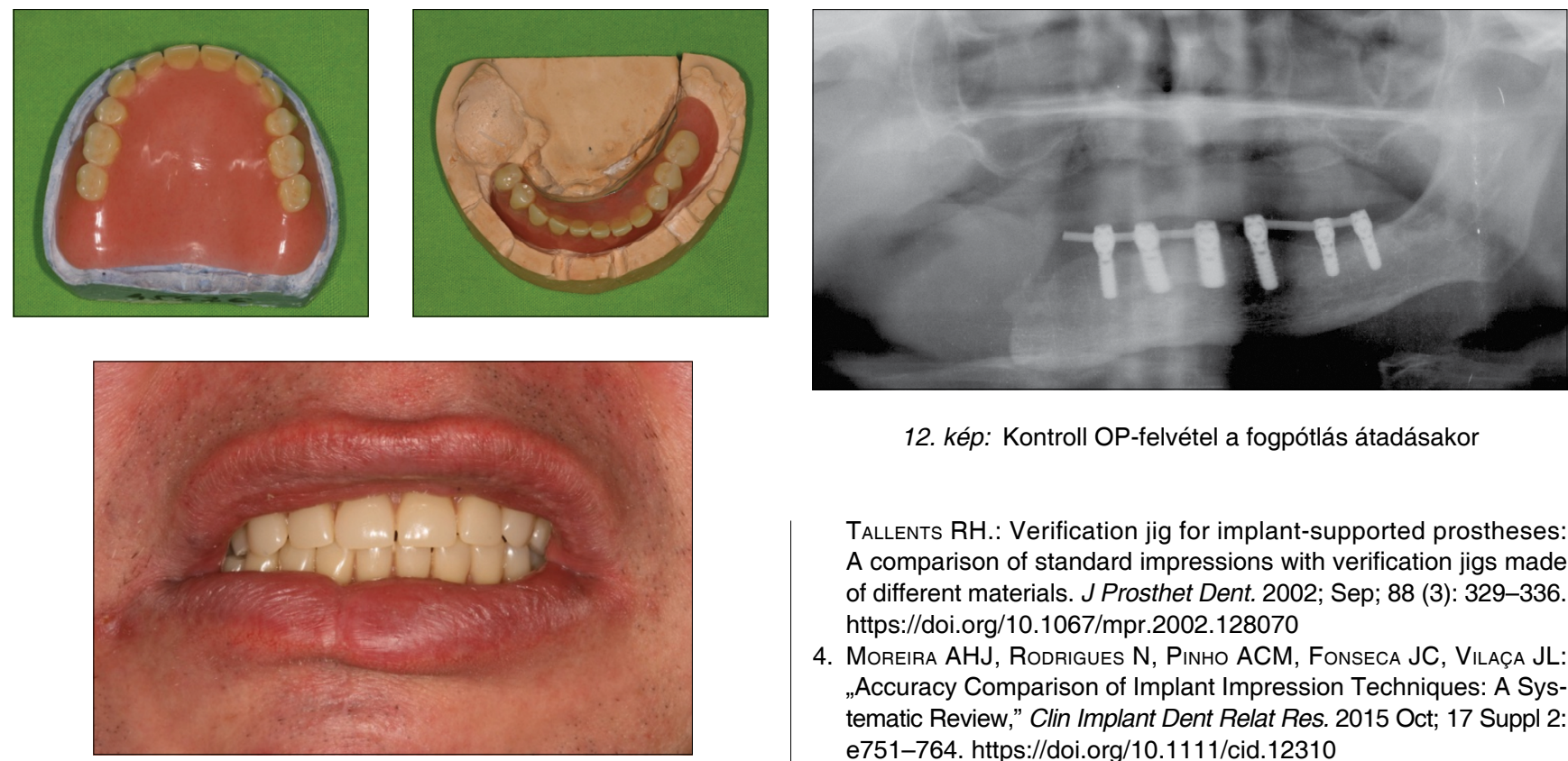

12. kép: Kontroll OP-felvétel a fogpótlás átadásakor

TALLENTS RH.: Verification jig for implant-supported prostheses: A comparison of standard impressions with verification jigs made of different materials. J Prosthet Dent. 2002; Sep; 88 (3): 329-336. https://doi.org/10.1067/mpr.2002.128070

4. Moreira AHJ, Rodrigues N, Pinho ACM, Fonseca JC, Vilaça JL: „Accuracy Comparison of Implant Impression Techniques: A Systematic Review," Clin Implant Dent Relat Res. 2015 Oct; 17 Suppl 2: e751-764. https://doi.org/10.1111/cid.12310

5. SzABó Gy: Szájsebészet, maxillofaciális sebészet, Semmelweis Kiadó, Budapest, 2004
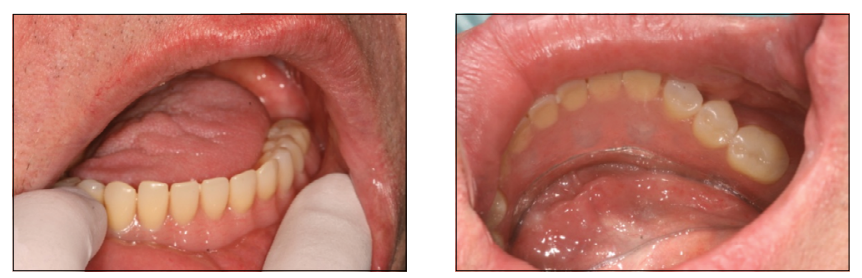

6. WHITE GE: Osseointegrated Dental Technology. London, Quintessence Publishing Co Ltd, 1993, 61., 123-124., 129.

11. kép: Az elkészült fogpótlások a mintán és a szájban

DÉRI T, KÁDÁR L

\section{Prosthetic rehabilitation of a hemimandibulectomy patient with the help of implant-retained prosthesis}

Case report

In the combined maxillo-facial and prosthetic rehabilitation one of the most difficult cases is the complex treatment of the hemimandibulectomy defects. The problem is, that in case of the lost continuity of the mandible's bony base, the support of the later denture is insufficient, and the bone-replacing soft tissues are not able to withstand the load of the denture baseplate. Usually the patients, who have such defects, are completely edentulous, and without rest teeth, the possibilities of making a well-functioning prostheses are not so optimal. On the other hand, some kind of temporomandibular joint disorder will occur, because the normal function is impossible with two separate pieces of the lower jaw. The implant retained removable dentures, especially the overdentures are very good variants of treatment by these kind of defects, because the very disadvantageous clinical-anatomical circumstances don't provide proper retention and stability for the prostheses. With the help of the implants we have the possibility to use ball-, bar-joint, push button or even magnetic retentive systems to avoid the denture's dislocation. Of course, the more implants we can use, the better the result will be. But we can say, just two implants can give so good stability, wich is inconceivable with the conventional edentulousness treatment methods.

Keywords: hemimandibulectomy, overdenture, implant, bar-joint, temporomandibular joint, stability 